\title{
Potenciálisan rákellenes hatású platinafémionok kölcsönhatása hidroxámsavakkal és származékaikkal
}

\author{
BUGLYÓ Péter ${ }^{\mathrm{a}}{ }^{*}$ és FARKAS Etelka ${ }^{\mathrm{a}}$ \\ ${ }^{a}$ Debreceni Egyetem, Természettudományi és Technológiai Kar, Szervetlen és Analitikai Kémiai Tanszék, Egyetem tér 1., \\ 4032 Debrecen, Magyarország
}

\section{Bevezetés}

A rákellenes hatású fémkomplexek fontos területet jelenthetnek a kór kezelésében, hiszen ezen vegyületek tulajdonságai (geometria, összetétel, töltés, termodinamikai stabilitás, ligandumcsere folyamatok, redoxi tulajdonságok stb.) széleskörűen szabályozhatók a központi fémion(ok) és a ligandumok módosításával. A jelenleg használt terápiás szerek között a síknégyzetes, $d^{8} \mathrm{Pt}$ (II) komplexek (1. ábra) kiemelkedő jelentőségủek elsősorban egyes szaporítószervi daganatok kezelésében. Ugyanakkor az alkalmazás során gyakran lépnek fel súlyos mellékhatások és alakul ki sejtrezisztencia, ami azzal magyarázható, hogy ezek a vegyületek nem szelektívek, nem csak a rákos sejtekben fejtik ki hatásukat. ${ }^{1,2}$

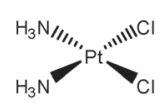

ciszplatin

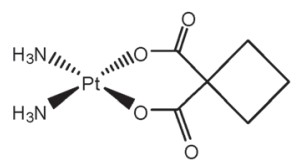

karboplatin

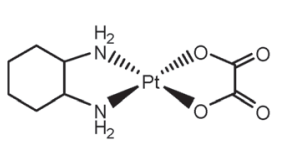

oxaliplatin
1. Ábra. A rákterápiában alkalmazott néhány platina(II) komplex szerkezeti képlete.

Alternatívát jelenthetnek az utóbbi évtizedekben a kutatás előterébe került egyéb platinafémion-tartalmú komplexek. ${ }^{3,4}$ Ezek egy jellegzetes csoportját képviselik az un. félszendvics szerkezetü, fémorganikus $\left[\left(\eta^{6}\right.\right.$-arén) $\left.\mathrm{M}(\mathrm{XY}) \mathrm{Z}\right]$ (arén = aromás ligandum; $\mathrm{M}=\mathrm{Ru}(\mathrm{II})$, Os(II)) és [( $\left.\left.\eta^{5}-\mathrm{Cp}\right) \mathrm{M}(\mathrm{XY}) \mathrm{Z}\right](\mathrm{Cp}=$ ciklopentadienil; $\mathrm{M}=\mathrm{Rh}(\mathrm{III})$, Ir(III), XY = kelátképző, $Z$ = egyfogú ligandum) összetételü vegyületek (2. ábra). Ezeknek a komplexeknek jellegzetes, „,zongoraszék" geometriájuk van; a hexa- vagy pentahapto koordinációjú arén vagy arenil ligandum mellett még három koordinációs helyre köthetnek donoratomok. A $\pi$-donor aromás rendszer egyrészt stabilizálja a fémion kis oxidációs állapotát, másrészt felelős a komplex hidrofób jellegéért, ami megfelelő molekuláris felismerést és így nagyobb biológiai hatékonyságot eredményezhet. ${ }^{5,6}$ A három koordinációs helyből kettőt általában egy $(\mathrm{N}, \mathrm{N}),(\mathrm{N}, \mathrm{O})$ vagy $(\mathrm{O}, \mathrm{O})$ donor kelátképző ligandum foglal el és a komplex biológiai hatásáért lehet felelős, míg a harmadik helyen egy egyfogú ligandum, például kloridion lehet. Utóbbi, oldatban könnyen vízmolekulára cserélődhet, így ez tekinthető a vegyület reaktív helyének. ${ }^{5,6}$

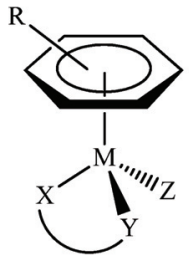

$\mathrm{M}=\mathrm{Ru}(\mathrm{II}), \mathrm{Os}(\mathrm{II})$

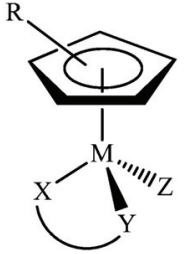

$\mathrm{M}=\mathrm{Rh}(\mathrm{III}), \mathrm{Ir}(\mathrm{III})$
2. Ábra. Félszendvics típusú platinafém komplexek sematikus szerkezete.

$\mathrm{Az} \mathrm{R}_{1} \mathrm{C}(\mathrm{O}) \mathrm{N}\left(\mathrm{R}_{2}\right) \mathrm{OH}$ általános összetételü hidroxámsavak régóta ismert, fontos biológiai hatású vegyületcsalád. $A z R_{1}$ alkil- vagy arilcsoportot jelölhet, míg $\mathrm{R}_{2}=\mathrm{H}$ esetén primer, $\mathrm{R}_{2}=$ alkil- vagy arilcsoport esetén szekunder hidroxámsavakról beszélünk. Előbbi ligandumok az NH deprotonálódása után a nitrogénen keresztül is képesek fémion-megkötésre, hidroximáto komplexeket kialakítva. A fó fémion-megkötőhely azonban az OH-csoport deprotonálódása után a két O-donoratom, melyek nagy stabilitású, öttagú hidroxamáto kelátot alakítanak ki a fémionokkal. Ezzel a kiváló komplexképző tulajdonsággal értelmezhető a hidroxámsavak jelentős biológiai szerepe. Így ezek a ligandumok fontos szerepet játszanak az alacsonyabb rendü élőlények fémion- $\left(\mathrm{Fe}^{3+}\right)$ felvételében és szállításában: a sziderofórok egyik családját is alkotják. ${ }^{7} \mathrm{~A}$ hidroxámsavak emellett hatékony inhibítorai számos fémiontartalmú biokatalizátornak, metalloenzimnek is. A hiszton-deacetiláz enzimek gátlására képes hidroxámsavak közül például a szuberoilanilid-hidroxámsavat (SAHA, 3. ábra) rákellenes szerként alkalmazzák elsősorban T-sejtes non-Hodgkin limfómák kezelésére. ${ }^{8}$<smiles>O=C(CCCCCCC(=O)Nc1ccccc1)NO</smiles>

3. Ábra. A szuberoilanilid-hidroxámmsav (SAHA) szerkezeti képlete.

A Debreceni Egyetem Bioszervetlen Kémiai Kutatócsoportjában a több évtizedes oldategyensúlyi tapasztalatokra támaszkodva valamint az utóbbi évtizedben kialakított preparatív infrastruktúra segítségével, egyebek mellett, a 2. ábrán látható, potenciálisan rákellenes hatású 
komplexeket képező fémionok kölcsönhatását vizsgáljuk különböző típusú bioligandumokkal. Oldategyensúlyi kutatásaink a fenti fémionok hidrolízis folyamatainak részletes feltérképezését, a ligandumokkal képződő komplexek összetételének, szerkezetének és stabilitásának vizsgálatát jelentik, míg a szilárd formában előállított és jellemzett komplexek biotranszformációs folyamatainak a tanulmányozása a szerkezet-biológiai hatás összefüggések megismerését segítheti.

Mivel a hidroxámsavak egyes képviselői bizonyítottan rákellenes hatásúak az utóbbi közel egy évtizedben szisztematikus vizsgálatokat végeztünk, egyebek mellett, ezen ligandumok és származékaik valamint a 2. ábrán bemutatott, ugyancsak jelentős biológiai potenciállal rendelkező platinafémionok közötti kölcsönhatások felderítésére. Ez a munka a területen már közölt eredményeinket összegzi. ${ }^{9-18}$

\section{Monohidroxámsavak kölcsönhatása félszendvics szerkezetü platinafémionokkal}

\subsection{Komplexképződés szilárd fázisban}

A fémion-ligandum kölcsönhatások feltérképezésére, a képződő vegyületek molekulaszerkezetének megismerésére, a jelenlévő egyéb segédligandumok a képződő komplexek szerkezetére, nuklearitására, stabilitására gyakorolt hatásának megértésére számos platinafém-hidroxamátot állítottunk elő és jellemeztünk szilárd fázisban különböző analitikai módszerekkel.

Eredményeink szerint a relatíve könnyen hozzáférhető $\left[\left(\eta^{6}-p \text {-cym }\right) \mathrm{MCl}_{2}\right]_{2} \quad(\mathrm{M}=\mathrm{Ru}, \quad \mathrm{Os} ; \quad p$-cym = 1-metil-4-izopropilbenzol) vagy $\left[\left(\eta^{5}-\mathrm{Cp}^{*}\right) \mathrm{MCl}_{2}\right]_{2}(\mathrm{M}=\mathrm{Rh}$, Ir) prekurzorokból illetve az ezekből nyerhető triflát vagy nitrát sókból metanolban, bázis jelenlétében jó hozammal állíthatók elő a monohidroxamát komplexek. Abban az esetben, ha nem vagy csak gyengén koordinálódni képes egyéb ligandum van a reakcióelegyben mind primer mind szekunder monohidroxámsavakkal kétmagvú, 2:2 összetételű komplexek képződését tapasztaltuk. ${ }^{9,10}$ Példaként a 4 . és 5. ábrán egy benzohidroxamáto és egy N-metilacehidroxamáto komplex egykristály röntgendiffracióval meghatározott molekulaszerkezetét tüntettük fel. Látható, hogy a ligandumok a karbonil oxigénjükkel egy-egy fémionhoz kapcsolódnak, míg a hidroxamát oxigének hídként kötik össze a két fémcentrumot telítve ezáltal azok koordinációs szféráját. A fémion és karbonil-O közötti kötéstávolságok egyértelmüen kisebbek, mint a fémion hidroxamát-O értékek. ${ }^{9,10}$

Egyéb, erősebb koordinációra képes egyfogú ligandumok jelenlétében úgy változik a képződő komplexek szerkezete, hogy a hidroxamátok öttagú $(\mathrm{O}, \mathrm{O})$ kelátot alakítanak ki és a harmadik koordinációs helyre az egyfogú ligandum lép be. A fentebb írottakra szolgáltat példát az $\left[\left(\eta^{6}-p-c y m\right) \mathrm{Os}(\right.$ meaha $\left.) \mathrm{Cl}\right]$ (6. ábra) és a $\left[\left(\eta^{6}-p\right.\right.$-cym $\left.) \mathrm{Ru}(\mathrm{bha})(\mathrm{py})\right] \mathrm{CF}_{3} \mathrm{SO}_{3}$ (7. ábra) molekulaszerkezete, melyekben egy kloridion vagy piridin (py) koordinálódásával semleges illetve kationos, zongoraszék szerkezetü komplexek képződtek. ${ }^{10}$

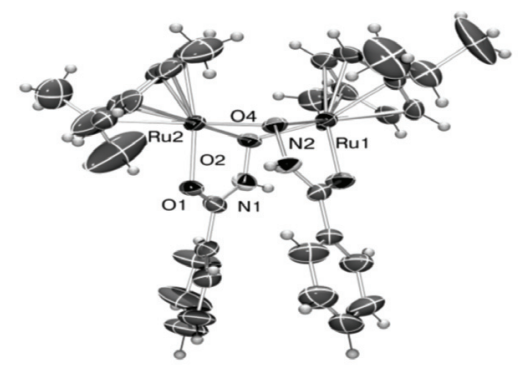

4. Ábra. A $\left[\left(\eta^{6}-p \text {-cym }\right) \operatorname{Ru}(\mu \text {-bha })\right]_{2}{ }^{2+}$ kation szerkezete.

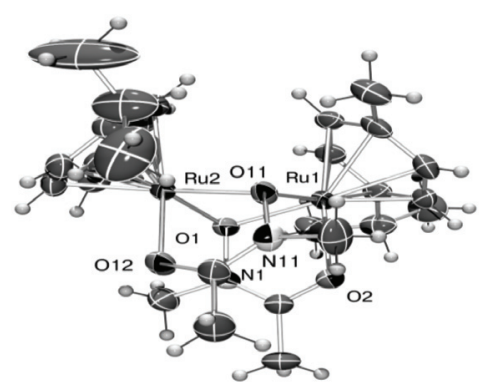

5. Ábra. A $\left[\left(\eta^{6}-p \text {-cym }\right) \operatorname{Ru}(\mu \text {-meaha })\right]_{2}^{2+}$ kation szerkezete.

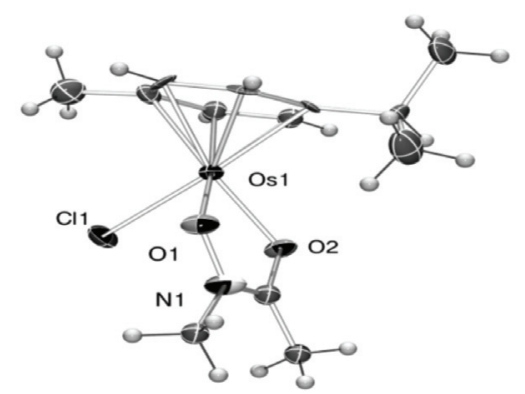

6. Ábra. A $\left[\left(\eta^{6}-p\right.\right.$-cym $) \mathrm{Os}($ meaha $\left.) \mathrm{Cl}\right]$ molekulaszerkezete.

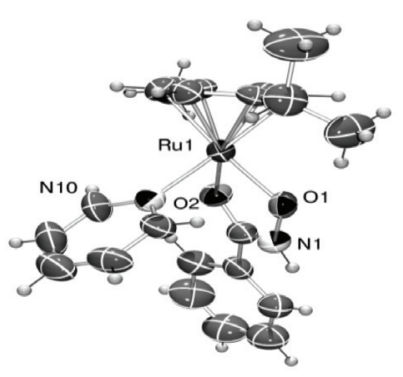

7. Ábra. A $\left[\left(\eta^{6}-p-c y m\right) R u(b h a) p y\right]^{+}$kation szerkezete.

Primer hidroxamát-Os(II) reakcióelegyekböl azonban nem tudtunk egységes terméket izolálni, amit a fémion kisebb redoxi stabilitásával értelmeztünk, összhangban a VO(IV)- vagy $\mathrm{Fe}(\mathrm{II})$-hidroxamát rendszerekbeli már leírt redoxi folyamatokkal. ${ }^{19,20}$ Ezt a kisebb stabilitást támasztja alá annak a vegyes vegyértékü $\mathrm{Os}{ }^{\mathrm{II}} / \mathrm{Os}^{\mathrm{VI}}$ vegyületnek a képződése is, ami az $\left[\left(\eta^{6} \text {-p-cym }\right) \mathrm{Os}(\text { meaha })\right]_{2}\left(\mathrm{CF}_{3} \mathrm{SO}_{3}\right)_{2}$ aceton/hexán oldatából aerób körülmények között kristályosodott ki. ${ }^{10} \mathrm{~A}$ nyert $\left[\left\{\left(\eta^{6}-p\right.\right.\right.$-cym $) \mathrm{Os}($ meaha $\left.\left.)\right\}(\mathrm{m}-\mathrm{O})\left\{\mathrm{OsO}(\text { meaha })_{2}\right\}\right] \mathrm{CF}_{3} \mathrm{SO}_{3}$ komplexben a félszendvics szerkezetű Os egységben két koordinációs 
helyet egy hidroxamát ligandum foglal el, míg a harmadik helyre kapcsolódó oxocsoport egy másik, oktaéderes $\mathrm{Os}=\mathrm{O}$ centrumhoz is kötődik (8. ábra). Itt az axiális helyzetü oxocsoportok mellett további két hidroxamát $(\mathrm{O}, \mathrm{O})$ kelát van jelen az Os(VI) koordinációs szférájában. ${ }^{10}$

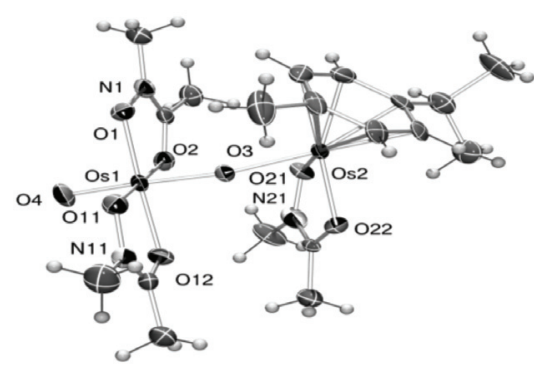

8. Ábra. A $\left[\left\{\left(\eta^{6}-p \text {-cym }\right) \mathrm{Os}(\text { meaha })\right\}(\mu-\mathrm{O})\left\{\mathrm{OsO}(\text { meaha })_{2}\right\}\right]^{+}$kation szerkezete.

\subsection{Komplexképződés vizes oldatban}

A félszendvics szerkezetü platinafémionok és a hidroxamát ligandumok közötti kölcsönhatást pH-potenciometriás, NMR, UV-Vis és ESI-TOF-MS módszerek kombinált alkalmazásával tanulmányoztuk azért, hogy meghatározzuk a képződő komplexek összetételét, stabilitási szorzat értékeit és hogy javaslatot tegyünk azok legvalószínübb oldatszerkezetére.

A számolásokhoz szükséges figyelembe venni a ligandumok protonálódási és a fémionok hidrolitikus folyamatait is. Utóbbi területen semmilyen irodalmi előzmény nem állt rendelkezésünkre a munka megkezdésekor, így részletesen tanulmányoztuk a modellül választott $\left[\left(\eta^{6}-p \text {-cym }\right) \mathrm{Ru}\left(\mathrm{H}_{2} \mathrm{O}\right)_{3}\right]^{2+}$ kation hidrolitikus folyamatait $0,20 \mathrm{M}$ klorid- illetve nitrátion ionerősség jelenlétében. ${ }^{9,12}$ Kimutattuk, hogy nitrátionok jelenlétében a pH növelésével kizárólag egy részecske, a $\left[\left\{\left(\eta^{6}-p-c y m\right) R u\right\}_{2}\left(m^{2}-\mathrm{OH}\right)_{3}\right]^{+}$képződik, melyben a két fémcentrumot három hidroxidion köt össze hídligandumként. $0,20 \mathrm{M} \mathrm{KCl}$ ionrősség mellett a 9. ábrán látható módon, $\mathrm{pH}=2$ esetén a fémion jelentős mértékben $\left[\left(\mathrm{h}^{6}-p \text {-cym }\right) \mathrm{Ru}\left(\mathrm{H}_{2} \mathrm{O}\right)_{2} \mathrm{Cl}\right]^{+}$ és $\left[\left\{\left(\eta^{6}-p \text {-cym }\right) \mathrm{Ru}\right\}_{2}\left(\mu^{2}-\mathrm{Cl}\right)_{3}\right]^{+}$formájában van jelen, majd a $\mathrm{pH}$ emelésével, a kloridionok cseréjével vegyes klorido/hidroxido komplexek is megjelennek a rendszerben. A gyengén de koordinálódni képes kloridionok a nagyobb pH-k tartományába tolják a fémion teljes hidrolízisét, a $\left[\left\{\left(\eta^{6}-p \text {-cym }\right) \mathrm{Ru}\right\}_{2}\left(\mu^{2}-\mathrm{OH}\right)_{3}\right]^{+}$komplex megjelenését. ${ }^{12}$

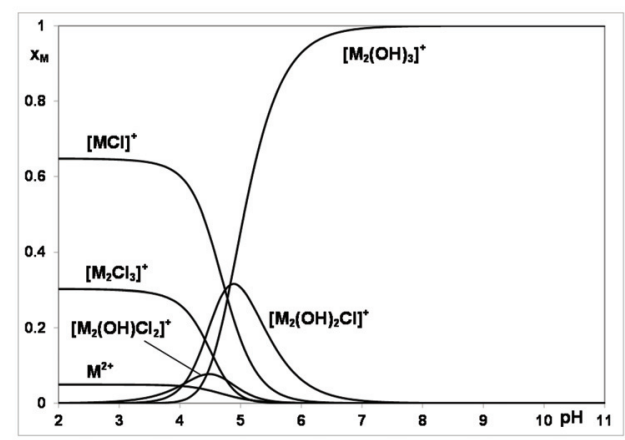

9. Ábra. $\mathrm{A} \mathrm{H} \mathrm{H}^{+}-\left[\left(\eta^{6}-p \text {-cym }\right) \mathrm{Ru}\left(\mathrm{H}_{2} \mathrm{O}\right)_{3}\right]^{2+}-\mathrm{Cl}^{-}$rendszerben képződő részecskék koncentráció eloszlási görbéi, $\mathrm{c}_{\mathrm{Ru}}=2 \mathrm{mM}, \mathrm{c}_{\mathrm{KCl}}=0.20 \mathrm{M}, \mathrm{t}=$ $25.0^{\circ} \mathrm{C}$. „,M” a $\left[\left(\eta^{6}-p\right.\right.$-cym $) \mathrm{Ru}$ egységet jelöli.
További vizsgálatokkal azt is kimutattuk, hogy a hexahapto kötésmódú aromás rendszer elektronellátottságával, a benzolgyürühöz kapcsolódó szubsztituensekkel a $\left[\left(\eta^{6} \text {-arén }\right) \mathrm{Ru}\left(\mathrm{H}_{2} \mathrm{O}\right)_{3}\right]^{2+}$ (arén = benzol, toluol, 1-metil-4izopropilbenzol, 1,3,5-triizopropilbenzol) kationok hidrolitikus sajátságai finomszabályozhatóak illetve, hogy a megfelelő $4 d$ és $5 d$ kationpárok $\left(\left[\left(\eta^{6}-p \text {-cym }\right) \mathrm{M}\left(\mathrm{H}_{2} \mathrm{O}\right)_{3}\right]^{2+} \mathrm{M}\right.$ $=\mathrm{Ru}, \mathrm{Os} ;\left[\left(\eta^{5}-\mathrm{Cp} \mathrm{p}^{*} \mathrm{M}\left(\mathrm{H}_{2} \mathrm{O}\right)_{3}\right]^{2+} \mathrm{M}=\mathrm{Rh}, \mathrm{Ir}\right)$ közül a nehéz platinafémek kationjai sokkal hajlamosabbak a hidrolízisre. $^{13}$

A monohidroxámsavakat is tartalmazó rendszerekben a csak $(\mathrm{O}, \mathrm{O})$ koordinációra képes szekunder reprezentatívokkal (pl. meahaH) széles pH-tartományban jelenlevő stabil, 1:1 komplex képződését igazoltuk, amelyet $\mathrm{pH}$ 8,5 felett vegyes hidroxido komplex képződése követ (10. ábra). ${ }^{9}$

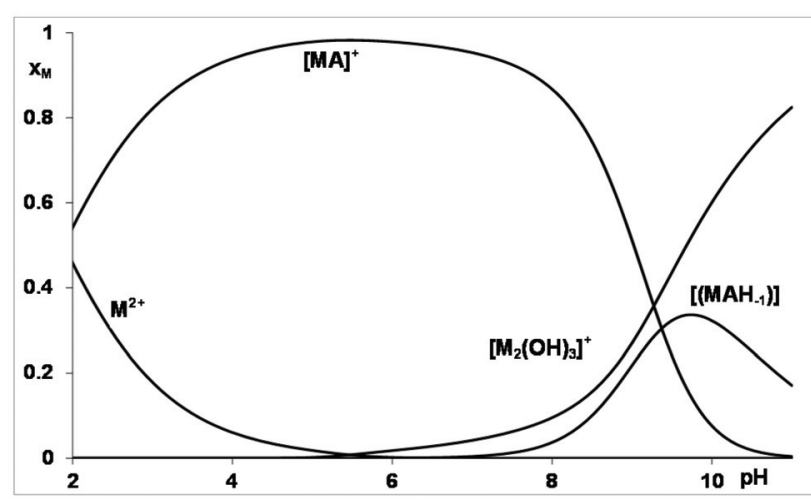

10. Ábra. $\mathrm{A}\left[\left(\eta^{6}-p \text {-cym }\right) \mathrm{Ru}\left(\mathrm{H}_{2} \mathrm{O}\right)_{3}\right]^{2+}$-meaha $(\mathrm{A})$ rendszerben képződő részecskék koncentráció eloszlási görbéi, $\mathrm{c}_{\mathrm{Ru}}=\mathrm{c}_{\text {meaha }}=2 \mathrm{mM}, \mathrm{I}=0.20 \mathrm{M}$ $(\mathrm{KCl}), \mathrm{t}=25.0^{\circ} \mathrm{C}$. ,M” a [( $\eta^{6}-p$-cym $) \mathrm{Ru}$ egységet jelöli.

Ugyanazen rendszerben a kölcsönhatás ${ }^{1} \mathrm{H}$ NMR-rel is kiválóan tanulmányozható volt. Ahogy azt a 11. ábra mutatja, pH 2,12-nél a két dublet, amelyek a fémionhoz kapcsolódó p-cimol izopropilmetil csoportjainak a jelei, két, az NMR időskálán lassú cserében álló részecskéhez tartozik. A független mérésekből ismert akvakomplex $(1,32 \mathrm{ppm})^{12}$ melletti új jel $(1,26 \mathrm{ppm})$ a $\left[\left(\eta^{6}-p \text {-cym }\right) \mathrm{Ru}(\text { meaha })\left(\mathrm{H}_{2} \mathrm{O}\right)\right]^{+}$ komplexhez rendelhető. A jel $\mathrm{pH} 8,0$ felett a nagyobb térerősség irányába eltolódik, ami egy olyan új részecske képződésére utal, amely gyors cserében áll az $\left[\left(\eta^{6}-p \text {-cym }\right) \mathrm{Ru}(\text { meaha })\left(\mathrm{H}_{2} \mathrm{O}\right)\right]^{+}$-val és megfeleltethetö $\left[\left(\eta^{6}-p\right.\right.$-cym)Ru(meaha) $\left.(\mathrm{OH})\right]$-nak. Az is megfigyelhetö, hogy a $\left[\left\{\left(\mathrm{h}^{6}-p-c y m\right) \mathrm{Ru}\right\}_{2}\left(\mu^{2}-\mathrm{OH}\right)_{3}\right]^{+}-$hoz tartozó dublet (1,20 ppm) csak pH 9,0 felett jelenik meg nagyobb mennyiségben; a ligandum tehát ezen rendszerben még 1:1 fémion-ligandum aránynál is hatékony fémionmegkötő. ${ }^{9}$

Primer hidroxámsavak (pl. ahaH) esetén, ahol a hidroxamát-NH deprotonálódása is bekövetkezhet, azt tapasztaltuk, hogy vizes oldatban 1:1 komplexek feltételezésével ugyancsak jól leírhatók a pH-potenciometriás titrálási görbék, azonban a $\mathrm{p} K_{\left[\left(\eta^{6}-p \text {-cym }\right) \mathrm{Ru}(\mathrm{ahah})\left(\mathrm{H}_{2} \mathrm{O}\right)\right]^{+}}=6,69$ értéke (meahaH esetén ez az érték 9,37), továbbá a rendszerben potenciometriás és NMR módszerrel is kimutatható $\left[\left(\mathrm{h}^{6}-p \text {-cym }\right) \mathrm{Ru}\left(\mathrm{ahaH}_{-1}\right)(\mathrm{OH})\right]^{-}$jelenléte arra utal, hogy a komplexképződés másképpen történik mint a szekunder hidroxamáttal. A fenti adatok és a DFT számítások eredményei 
alapján a formálisan $\left[\left(\eta^{6}-p\right.\right.$-cym $\left.) \mathrm{Ru}(\mathrm{aha})(\mathrm{OH})\right]$ összetételü részecske képződése a primer hidroxamáttal azért kedvezményezett, mert így stabil intermolekuláris H-kötés tud kialakulni a komplexben (11. ábra). A pH további növelésével, a H-kötés felbomlásával $\left[\left(\eta^{6}-p \text {-cym }\right) \mathrm{Ru}\left(\mathrm{ahaH}_{-1}\right)(\mathrm{OH})\right]^{-}$jön létre az erösen lúgos $\mathrm{pH}$ tartományban; megállapítható tehát, hogy a primer hidroxámsav kiváló komplexképzője ezen fémionnak. ${ }^{17}$

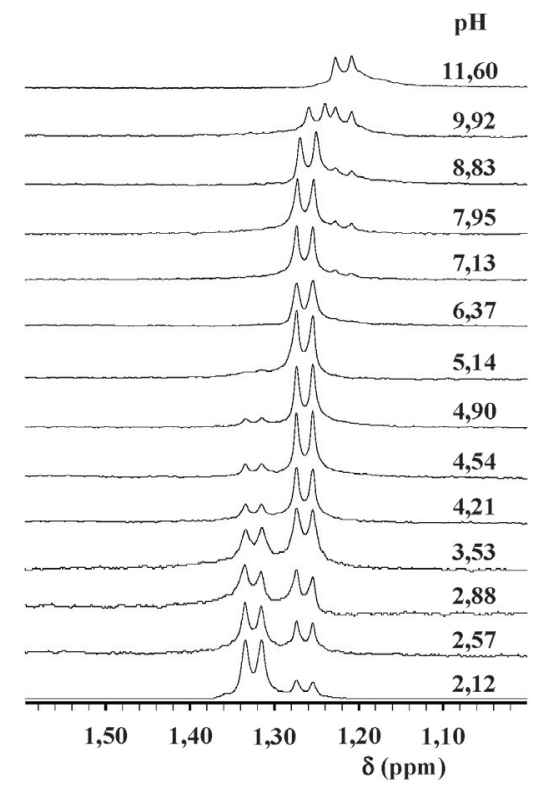

11. Ábra. $\mathrm{A}\left[\left(\eta^{6}-p \text {-cym }\right) \mathrm{Ru}\left(\mathrm{H}_{2} \mathrm{O}\right)_{3}\right]^{2+}$-meaha rendszer pH-függő NMR spektrumainak alifás tartománya, $\mathrm{c}_{\mathrm{Ru}}=\mathrm{c}_{\text {meaha }}=2 \mathrm{mM}, \mathrm{I}=0.20 \mathrm{M}(\mathrm{KCl}), \mathrm{t}$ $=23{ }^{\circ} \mathrm{C}$.

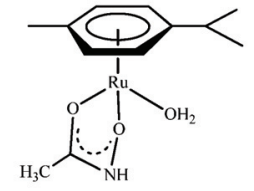

$\left[\left(\eta^{6}-p-c y m\right) R u(a h a)\left(H_{2} \mathrm{O}\right)\right]^{+}$

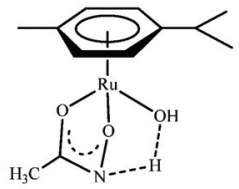

$\left[\left(\eta^{6}-p-c y m\right) \operatorname{Ru}(\mathrm{aha})(\mathrm{OH})\right]$

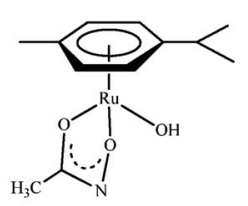

$\left[\left(\eta^{6}-p-\mathrm{cym}\right) \mathrm{Ru}\left(\mathrm{ahaH}_{-1}\right)(\mathrm{OH})\right]^{-}$
12. Ábra. $A\left[\left(\eta^{6}-p \text {-cym }\right) \mathrm{Ru}\left(\mathrm{H}_{2} \mathrm{O}\right)_{3}\right]^{2+}$-aha rendszerben képződő komplexek javasolt oldatszerkezete.

\subsection{A komplexek antiproliferatív tulajdonságai}

A szilárdan előállított komplexek közül néhánnyal biológiai teszteket is végeztünk ráksejt vonalakon, meghatározva a vegyületek $\mathrm{IC}_{50}$ értékeit. Eredményeink azt mutatták, hogy az alkalmazott A2780 és A2780cisR (ciszplatin rezisztens) sejtvonalaton a megvizsgált komplexek nem mutattak antiproliferatív hatást a vizsgált $0-200 \mu \mathrm{M}$ koncentráció tartományban. ${ }^{9}$ A negatív eredmények azzal értelmezhetőek, hogy bár nagy stabilitású komplexek képződnek fiziológiás $\mathrm{pH}-\mathrm{n}$ a rendszerekben, ami megakadályozza a biológiailag inaktív $\quad\left[\left\{\left(\eta^{6}-p \text {-cym }\right) \mathrm{Ru}\right\}_{2}\left(\mu^{2}-\mathrm{OH}\right)_{3}\right]^{+} \quad$ jelentősebb koncentrációban való megjelenését, a képződő 1:1 összetételű komplexek kinetikai inertsége valószínüleg nem megfelelő, így már azelőtt részt vesznek biotranszformációs reakciókban, mielőtt a célsejteket elérnék.

\section{Aminohidroxámsavak kölcsönhatása félszendvics szerkezetű platinafémionokkal}

$\mathrm{Az}$ aminohidroxamátok olyan aminokarboxilátokból levezethető molekulák, amelyekben a karboxilátcsoport hidroxamátra van cserélve. Ezekben a kelátképző ligandumokban a hidroxamátcsoport oxigénjei mellett a hidroxamát-N és az aminocsoport részvételével egy további donoratompár is rendelkezésre áll fémionok megkötésére. Ahogyan az a 13. ábrán bemutatott, a vizsgálatainkban szereplő különböző aminohidroxamátok szerkezetén látható, a kialakuló $(\mathrm{N}, \mathrm{N})$ kelát gyürütagszáma és így stabilitása is szabályozhtó az összekötő lánc hosszának a változtatásával. Mivel az $\mathrm{M}-\mathrm{N}$ ( $\mathrm{M}=$ félszendvics vagy síknégyzetes szerkezetű platinafémion) kötés jóval inertebb az $\mathrm{M}-\mathrm{O}$ kötésnél, így azt feltételeztük, hogy az aminohidroxamátokkal képződő platinafém komplexekben a ligandumcsere folyamatok sebessége kisebb lesz, ami megnövekedett biológiai aktivitást eredményezhet.

\subsection{Komplexképződés oldatfázisban}

A modellül választott $\left[\left(\eta^{6}-p \text {-cimol }\right) \mathrm{Ru}\left(\mathrm{H}_{2} \mathrm{O}\right)_{3}\right]^{2+}$ és a 13 . ábrán bemutatott $\alpha$-alahaH, $\beta$-alahaH illetve $\gamma$-abhaH közötti komplexképződési folyamatokről megállapítottuk, hogy mindhárom ligandum különböző protonáltsági fokú 1:1 és 2:1 fémion-ligandum arányú részecskéket képez (14. ábra); az $(\mathrm{N}, \mathrm{N})$ koordinációjú ligandumot is tartalmazó $\left[\left\{\left(\eta^{6}-p \text {-cym }\right) \mathrm{Ru}\right\}_{2}\left(\mu^{2} \text {-aminohidroxamátH }{ }_{-1}\right)\right]^{2+}$ komplexionok stabilitása a $\gamma \rightarrow \alpha$ irányban nő. ${ }^{18} \mathrm{~A}$ várakozásnak megfelelően, a ligandumok ezen sorrendjében, a komplexképződési folyamatok az aminocsoport jelenlétében jelentősen lelassultak, megbízható számszerü adatokat tartalmazó oldategyensúlyi modellt csak a g-abhaH rendszerében tudtunk számolni (reprezentatív példa a 14 . ábrán látható).<smiles>NCC(=O)NO</smiles>

$\alpha$-alahaH<smiles>NCCC(=O)NO</smiles>

$\beta$-alahaH<smiles>NCCCC(=O)NO</smiles>

$\gamma-\mathrm{abhaH}$
13. Ábra. A vizsgált aminohidroxámsavak szerkezeti képletei.

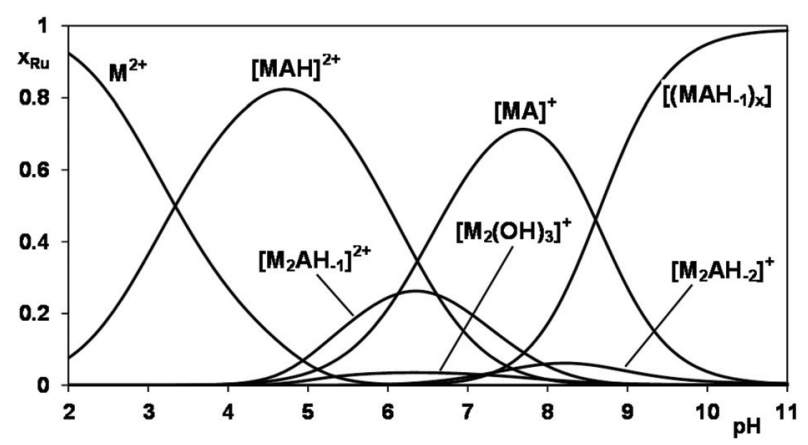

14. Ábra. A $\left[\left(\eta^{6}-p \text {-cym }\right) \mathrm{Ru}\left(\mathrm{H}_{2} \mathrm{O}\right)_{3}\right]^{2+}$-g-abha (A) rendszerben képződő részecskék koncentráció eloszlási görbéi, $\mathrm{c}_{\mathrm{Ru}}=\mathrm{c}_{\mathrm{g} \text {-abha }}=2 \mathrm{mM}, \mathrm{I}=0.20 \mathrm{M}$ $\left(\mathrm{KNO}_{3}\right), \mathrm{t}=25.0^{\circ} \mathrm{C}$, „M” a $\left[\left(\eta^{6}-p\right.\right.$-cym $) \mathrm{Ru}$ egységet jelöli. 
Az ${ }^{1} \mathrm{H}$ NMR spektrumok a 2,0 $<\mathrm{pH}<7,0$ tartományban konzisztensek voltak a koncentráció eloszlási görbékkel, ennél lúgosabb minták esetén azonban, azok összetett volta, nem tette lehetővé a jelek teljes hozzárendelését. Ugyanakkor az egyensúlyi modellekben szereplő egyes részecskeféleségekre ESI-TOF-MS technikával nyert mért és számított $\mathrm{m} / \mathrm{z}$ értékek kiváló egyezése (1. táblázat) is alátámasztotta a felállított oldategyensúlyi modellt. Függetlenül a nitrogének részvételével kialakuló $(\mathrm{N}, \mathrm{N})$ kelátgyürük tagszámától mindhárom aminohidroxamát kiváló liganduma a fémionnak és hatékonyan képes megakadályozni annak hidrolízisét fiziológiás pH-n. ${ }^{18}$

\begin{tabular}{|c|c|c|}
\hline Récsecske & $\begin{array}{c}\mathrm{m} / \mathrm{z} \\
\text { (mért) }\end{array}$ & $\begin{array}{c}\mathrm{m} / \mathbf{z} \\
\text { (számított) }\end{array}$ \\
\hline$\left[\left(\eta^{6}-p-c y m\right) R u C l\right]^{+}$ & 270.980 & 270.982 \\
\hline$\left[\left(\eta^{6}-p \text {-cym }\right) \operatorname{Ru}(\alpha \text {-alaha })\right]^{+}$ & 339.069 & 339.064 \\
\hline$\left[\left(\left(\eta^{6}-p-c y m\right) R u\right)_{2}(\alpha \text {-alahaH }-1)\right]^{2+}$ & 286.535 & 286.536 \\
\hline$\left[\left(\left(\eta^{6}-p \text {-cym }\right) \mathrm{Ru}\right)_{2}\left(\alpha \text {-alahaH }{ }_{-1}\right)_{2}\right]+\mathrm{H}^{+}$ & 677.150 & 677.123 \\
\hline$\left[\left(\left(\eta^{6}-p \text {-cym }\right) \mathrm{Ru}\right)_{2}\left(\alpha-\text { alahaH }_{-1}\right)_{2}\right]+\mathrm{K}^{+}$ & 715.109 & 715.078 \\
\hline$\left[\left(\eta^{6}-p \text {-cym }\right) \operatorname{Ru}(\beta \text {-alaha })\right]^{+}$ & 339.059 & 339.064 \\
\hline$\left[\left(\eta^{6}-p-c y m\right) \operatorname{Ru}\left(\beta-\right.\right.$ alahaH $\left.\left._{-1}\right)\right]+\mathrm{K}^{+}$ & 377.014 & 377.020 \\
\hline$\left[\left(\left(\eta^{6}-p-c y m\right) R u\right)_{2}\left(\beta \text {-alahaH }{ }_{-1}\right)_{2}\right]+\mathrm{H}^{+}$ & 677.117 & 677.123 \\
\hline$\left[\left(\left(\eta^{6}-p \text {-cym }\right) \mathrm{Ru}\right)_{2}\left(\beta \text {-alahaH }{ }_{-1}\right)_{2}\right]+\mathrm{K}^{+}$ & 715.071 & 715.078 \\
\hline$\left[\left(\eta^{6}-p-c y m\right) \operatorname{Ru}(\gamma-\mathrm{abha})\right]^{+}$ & 353.075 & 353.080 \\
\hline$\left[\left(\left(\eta^{6}-p-c y m\right) R u\right)_{2}\left(\gamma-a_{b h a H}\right)(C l)\right]^{+}$ & 623.051 & 623.056 \\
\hline$\left[\left(\left(\eta^{6}-p-c y m\right) R u\right)_{2}\left(\gamma-a b h a H_{-1}\right)_{2}\right]+\mathrm{H}^{+}$ & 705.149 & 705.154 \\
\hline$\left[\left(\left(\eta^{6}-p-c y m\right) R u\right)_{2}\left(\gamma-a b h a H_{-1}\right)_{2}\right]+\mathrm{K}^{+}$ & 743.104 & 743.110 \\
\hline
\end{tabular}

1. Táblázat. $\mathrm{A}\left[\left(\eta^{6}-p \text {-cym }\right) \mathrm{Ru}\left(\mathrm{H}_{2} \mathrm{O}\right)_{3}\right]^{2+}$-aminohidroxamát rendszerekben detektált részecskék mért és számított m/z értékei 1:1 fémion ligandum aránynál.

\subsection{Komplexképződés szilárd fázisban}

$\mathrm{Az}$ oldategyensúlyi modellben, különösen az a-alahaH rendszerben domináns $\left[\left\{\left(\eta^{6}-p-c y m\right) R u\right\}_{2}\left(\mu^{2} \text {-a-alahaH } H_{-1}\right)\right]^{2+}$ részecske stabilitásának, pontos kötésmódjának és molekulaszerkezetének a megismerésére néhány aminohidroxamát komplexet szilárd fázisban is előállítottunk és különböző analitikai módszerekkel karakterizáltunk. Az egykristályként is megvizsgált $\left[\left\{\left(\eta^{6}-p \text {-cym }\right) \mathrm{Ru}\right\}_{2}\left(\mu^{2}-\alpha\right.\right.$-alahaH $\left.\left.{ }_{-1}\right)\left(\mathrm{H}_{2} \mathrm{O}\right) \mathrm{Br}\right] \mathrm{Br} \bullet \mathrm{H}_{2} \mathrm{O} \quad$ és $\left[\left\{\left(\eta^{6}-p\right.\right.\right.$-cym $) \mathrm{Ru}_{2}\left(\mu^{2}-\alpha\right.$-alahaH $\left.\left.{ }_{-1}\right)\left(\mathrm{H}_{2} \mathrm{O}\right) \mathrm{Cl}\right] \mathrm{BF}_{4} \cdot \mathrm{H}_{2} \mathrm{O}$ molekulaszer-kezete a 15 . és 16 . ábrán látható. ${ }^{18}$

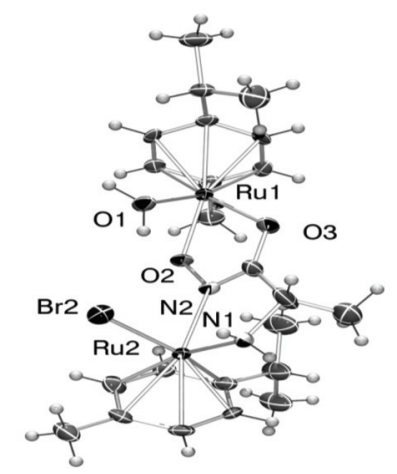

15. Ábra. $\mathrm{A}\left[\left\{\left(\eta^{6}-p\right.\right.\right.$-cym $) \mathrm{Ru}_{2}\left(\mu^{2}\right.$-á-alahaH $\left.\left.\mathrm{H}_{-1}\right)\left(\mathrm{H}_{2} \mathrm{O}\right) \mathrm{Br}\right] \mathrm{Br} \cdot \mathrm{H}_{2} \mathrm{O}$ molekula-szerkezete.

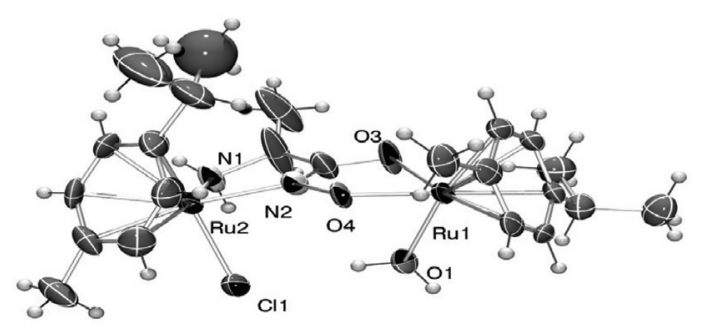

16. Ábra. $\mathrm{A}\left[\left\{\left(\eta^{6}-p-\mathrm{cym}\right) \mathrm{Ru}\right\}_{2}\left(\mu^{2}-\alpha\right.\right.$-alahaH $\left.\left.\mathrm{H}_{-1}\right)\left(\mathrm{H}_{2} \mathrm{O}\right) \mathrm{Cl}\right] \mathrm{BF}_{4} \cdot \mathrm{H}_{2} \mathrm{O}$ molekulaszerkezete.

Mindkét komplexben a ligandum egy fémionhoz hidroxamát $(\mathrm{O}, \mathrm{O})$ kelátot képezve, míg a másikkal a hidroximáto-N és az aminocsoport részvételével koordinálódik. Az $(\mathrm{N}, \mathrm{N})$ kelát mellett a fémion harmadik koordinációs helyét egy halogenidion, míg az $(\mathrm{O}, \mathrm{O})$ kelátok kiegészítéseként egy-egy vízmolekula foglalja el.

\subsection{A komplexek antiproliferatív tulajdonságai}

A szilárd formában jellemzett kétmagvú aminohidroxamát komplexek antiproliferatív hatását is megvizsgáltuk A2780, MCF-7, SKOV-3, HCT-116 és HeLa ráksejt vonalakon. A biológiai tesztek eredményei alapján a komplexek nem mutattak citotoxicitást a vizsgált $0-200 \mathrm{mM}$ koncentráció tartományban. ${ }^{18} \mathrm{Az}$ inaktivitás alapján feltételezhető, hogy az aminocsoport által biztosított kinetikai inertségnövekedés még nem megfelelö, a vizsgált kétmagvú komplexek oldatbeli átalakulása hamarabb megtörténik, mint ahogy hatásukat ki tudnák fejteni.

\section{4. Összefoglalás}

A jelenleg a rákterápiában alkalmazott Pt(II) komplexek mellékhatásai illetve a gyakran kialakuló sejtrezisztencia miatt intenzív kutatómunka folyik szelektívebb, kisebb dózisban is hatékony, kevesebb mellékhatással rendelkező fémion-tartalmú szerek kifejlesztésére. Fontos alternatívát jelenthetnek olyan egyéb platinafém vegyületek, amelyekben a fémion bizonyítottan bioaktív kis oxidációs állapota fémorganikus vegyületként arén vagy arenil ligandummal stabilizálható. Ezek a komplexek a szervezetben biotranszformációs reakciók során átalakulhatnak, így a megfelelő $\left[\left(\eta^{6} \text {-arén }\right) \mathrm{M}\left(\mathrm{H}_{2} \mathrm{O}\right)_{3}\right]^{2+}(\mathrm{M}=$ $\mathrm{Ru}$, Os) vagy $\left[\left(\eta^{5}-\mathrm{Cp}^{*}\right)\left(\mathrm{H}_{2} \mathrm{O}\right)_{3}\right]^{2+}(\mathrm{M}=\mathrm{Rh}, \mathrm{Ir})$ kationok, mint modellek, komplexképződési folyamatainak tanulmányozása fontos információkkal szolgálhat a szerkezet-biológiai hatás összefüggések feltérképezésében.

Az $\mathrm{R}_{1} \mathrm{C}(\mathrm{O}) \mathrm{N}\left(\mathrm{R}_{2}\right) \mathrm{OH}$ összetételű hidroxámsavak egyes képviselői, például a hiszton deacetiláz inhibítor SAHA, ugyancsak rákellenes hatásúak. Munkánk célja a két bioaktív egység összekapcsolásával új, platinafém-hidroxamát komplexek előállítása, jellemzése és oldatbeli viselkedésének a megismerése volt.

Mivel a fenti fémionok hidrolitikus tulajdonságaira vonatkozóan nem álltak rendelkezésre számszerü adatok az irodalomban, munkánk kezdetén részletesen tanulmányoztunk ezeket a folyamatokat. Megállapítottuk, hogy kloridionok 
távollétében egy trihidroxid-hidas kétmagvú részecske, $\left[\left\{\left(\eta^{6} \text {-arén }\right) \mathrm{M}\right\}_{2}\left(\mu^{2}-\mathrm{OH}\right)_{3}\right]^{+}(\mathrm{M}=\mathrm{Ru}, \mathrm{Os})$ képződik és van jelen $\mathrm{pH}$ 7-nél. $\mathrm{I}=0,20 \mathrm{M} \mathrm{KCl}$ ionerősség jelenlétében, $\mathrm{pH}=2$ esetén, a fémionok $\quad\left[\left(\eta^{6} \text {-arén) } \mathrm{M}\left(\mathrm{H}_{2} \mathrm{O}\right)_{2} \mathrm{Cl}\right]^{+}\right.$és $\left[\left\{\left(\eta^{6} \text {-arén }\right) \mathrm{M}\right\}_{2}\left(\mu^{2}-\mathrm{Cl}\right)_{3}\right]^{+}$formájában vannak jelen, majd a $\mathrm{pH}$ emelésével, a kloridionok cseréjével vegyes klorido/hidroxido komplexek jelennek meg a rendszerekben; a teljes hidrolízist a kloridionok visszaszorítják.

Eredményeink alapján mind a primer mind a szekunder monohidroxamátok nagy stabilitású, 1:1 összetételü komplexeket képeznek vizes oldatban a fémionokkal, öttagú $(\mathrm{O}, \mathrm{O})$ kelátokat kialakítva. A primer hidroxamátokkal, ahol a hidroxamát-NH deprotonálódására is lehetőség van, belső hidrogén-híddal stabilizált részecskét azonosítottunk. Szilárd fázisban mindkét ligandumtípus olyan 2:2 sztöchiometriájú komplexeket képez a félszendvics szerkezetü fémionokkal, amelyekben a ligandumok karbonil-O-jei egy-egy fémionhoz kapcsolódnak, míg hidroxamát-O-jei hídként kötik össze a két egységet. Egyes $\mathrm{Ru}(\mathrm{II})$ és Os(II) komplexek citotoxikológiai vizsgálata A2780 és A2780cisR sejtvonalakon nem mutatta azok aktivitását, amit a komplexek nem megfelelőn nagy kinetikai inertségével értelmeztünk.

A vizsgált fémionokkal különböző méretű $(\mathrm{N}, \mathrm{N})$ kelát kialakítására is képes a-, b- és g-aminohidroxamátokkal az első két esetben lassú komplexképződési folyamatokat tapasztaltunk, összhangban az M-N kötés inertebb karakterével. Minden rendszerben kimutattuk, hogy a ligandumok egy második fémion megkötésével stabil $\left[\mathrm{M}_{2} \mathrm{AH}_{-1}\right]^{+}$összetételü komplexeket is képeznek és hatékonyan képesek meggátolni a fémionok hidrolízisét a lúgos pH-tartományban. Az $(\mathrm{O}, \mathrm{O})$ és $(\mathrm{N}, \mathrm{N})$ kötésmódú kétmagvú komplexeket szilárdan is előállítottuk és egyebek mellett egykristály röntgendiffrakciós módszerrel jellemeztük. Különböző ráksejtvonalakon történt in vitro vizsgálatok eredményei azt mutatták, hogy a mikromólos koncentráció tartományban a $\mathrm{Ru}(\mathrm{II})$ komplexeknek nincs jelentős citotoxikus hatása.

\section{Köszönetnyilvánítás}

A közleményben bemutatott munka az OTKA (K112317) és a COST CM1105 anyagi támogatásával készült. A szerzők köszönetet mondanak valamennyi társszerzőnek, elsősorban Dr. Bíró Lindának, Dr. Bényei Attilának, Dr. Denise Egan-nak és Prof. Jana Kasparkova-nak az eredményekhez való jelentős hozzájárulásukért.

\section{Hivatkozások}

1. Jakupec, M.A.; Galanski, M.; Arion V.B.; Hartinger C.G.; Keppler, B.K. Dalton Trans. 2008, 183-194.

https://doi.org/10.1039/B712656P

2. Florea, A-F.; Büsselberg, D. Cancers 2011, 3, 1351-1371. https://doi.org/10.3390/cancers3011351

3. Yan, Y.K.; Melchart, M.; Habtemariam, A; Sadler, P.J. Chem. Commun. 2005, 4764-4776.

https://doi.org/10.1039/b508531b

4. Süss-Fink, G. Dalton Trans. 2010, 39, 1673-1688 https://doi.org/10.1039/B916860P

5. Bruijnincx, P.C.A.; Sadler, P.J. Adv. Inorg. Chem. 2009, 61, 1-62. https://doi.org/10.1016/S0898-8838(09)00201-3

6. Gasser, G.; Metzler-Nolte, N. Curr. Op. Chem. Biol. 2012, 16, 84-91. https://doi.org/10.1016/j.cbpa.2012.01.013

7. Griffith, D.; Devocelle, M.; Marmion, C.J. In Amino Acids, Peptides and Proteins in Organic Chemistry; Hughes, A.B.; Ed.; 2009; Vol. 2, pp 93-137.

8. Mann, B.S.; Johnson, J.R.; Cohen, M.H.; Justice, R; Pazdur, R. The Oncologist 2007, 12, 1247-1252.

https://doi.org/10.1634/theoncologist.12-10-1247

9. Buglyó, P.; Farkas, E. Dalton Trans. 2009, 8063-8070. https://doi.org/10.1039/b908173a

10. Godó, A.J.; Bényei, A.Cs.; Duff, B.; Egan, D.A.; Buglyó, P. RSC Advances, 2012, 2, 1486-1495.

https://doi.org/10.1039/C1RA00998B

11. Bíró, L.; Hüse, D.; Bényei, A.Cs.; Buglyó, P. J. Inorg. Biochem. 2012, 116, 116-125 https://doi.org/10.1016/j.jinorgbio.2012.07.020

12. Bíró, L.; Farkas, E.; Buglyó, P. Dalton Trans., 2012, 41, 285-291 https://doi.org/10.1039/C1DT11405K

13. Bíró, L.; Godó, A.J.; Bihari, Zs.; Garribba, E.; Buglyó P. Eur. J. Inorg. Chem., 2013, 3090-3100 https://doi.org/10.1002/ejic.201201527

14. Bíró, L.; Balogh, E.; Buglyó, P. J. Organomet. Chem., 2013, 734, 61-68 https://doi.org/10.1016/j.jorganchem.2012.11.023

15. Hüse, D.; Bíró, L.; Patalenszki, J.; Bényei, A.Cs.; Buglyó, P. Eur. J. Inorg. Chem., 2014, 5204-5216 https://doi.org/10.1002/ejic.201402559

16. Patalenszki, J.; Bíró, L.; Bényei, A.Cs.; Muchova, T.R.; Kasparkova, J.; Buglyó, P. RSC Advances, 2015, 5, 8094-8107 https://doi.org/10.1039/C4RA15649H

17. Parajdi-Losonczi, P.L.; Farkas, E.; Buglyó, P. nem közölt eredmények

18. Parajdi-Losonczi, P.L.; Bényei, A.Cs.; Kováts, É.; Timári, I., Radosova Muchova T.; Novohradsky, V.; Kasparkova, J.; Buglyó, P. J. Inorg. Biochem. 2016, 160, 236-245 https://doi.org/10.1016/j.jinorgbio.2016.02.032

19. Buglyó, P.; Pótári, N. Polyhedron 2005, 24, 837-845 https://doi.org/10.1016/j.poly.2005.03.007

20. Farkas, E.; Enyedy, É.A.; Zékány, L.; Deák, Gy. J. Inorg. Biochem. 2001, 83, 107-114. https://doi.org/10.1016/S0162-0134(00)00197-5 


\section{Interaction between platinum metal ions with anticancer potential and hydroxamic acids or their derivatives}

Platinum(II) complexes currently used in cancer therapy are known to have serious side effects and often drug resistance develops during the treatments. Therefore the development of novel metal complexes with higher selectivity and effectivity at even lower concentration is currently in the focus of intensive research. Half-sandwich type platinum metal complexes with promising antiproliferative potential represent an important option in this field. After administration these complexes may be involved in various biotransformation reactions therefore the study of the complex formation processes of $\left[\left(\mathrm{h}^{6} \text {-arene }\right) \mathrm{M}\left(\mathrm{H}_{2} \mathrm{O}\right)_{3}\right]^{2+}(\mathrm{M}=\mathrm{Ru}$, Os) or $\left[\left(h^{5}-\mathrm{Cp}^{*}\right)\left(\mathrm{H}_{2} \mathrm{O}\right)_{3}\right]^{2+}(\mathrm{M}=\mathrm{Rh}, \mathrm{Ir})$ cations as models can provide with valuable informations regarding structure-activity relationship.

Among other chelators, some representatives of the ligand family hydroxamic acids with $\mathrm{R}_{1} \mathrm{C}(\mathrm{O}) \mathrm{N}\left(\mathrm{R}_{2}\right) \mathrm{OH}$ general formula also exhibit proven anticancer activity. Suberoylanilid hydroxamic acid (SAHA) with histone deacetylase inhibitor activity, for example, is currently used in the treatment of cutaneous T-cell lymphoma. The aim of our work, therefore, was to incorporate these bioactive entities into one molecule with the synthesis and characterization of novel half-sandwich type hydroxamate complexes and to explore the composition and stability of the complexes formed in these systems under physiologically relevant conditions.

Since no information was available at the beginning of our work on the hydrolysis of the above model cations detailed solution equilibrium studes have been carried out in this field. It was found that in the absence of chloride ions a single hydrolytic product, $\left[\left\{\left(\eta^{6} \text {-arene }\right) \mathrm{M}\right\}_{2}\left(\mu^{2}-\mathrm{OH}\right)_{3}\right]^{+}(\mathrm{M}=\mathrm{Ru}, \mathrm{Os})$ with three bridging hydroxide ligands is present at $\mathrm{pH}=7$. Using $0.20 \mathrm{M} \mathrm{KCl}$ ionic strength, under acidic conditions beside the aquo complex, $\left[\left(\eta^{6} \text {-arene }\right) \mathrm{M}\left(\mathrm{H}_{2} \mathrm{O}\right)_{3}\right]^{2+}, \quad\left[\left(\eta^{6} \text {-arene }\right) \mathrm{M}\left(\mathrm{H}_{2} \mathrm{O}\right)_{2} \mathrm{Cl}\right]^{+} \quad$ and $\left[\left\{\left(\eta^{6} \text {-arene }\right) \mathrm{M}\right\}_{2}\left(\mu^{2}-\mathrm{Cl}\right)_{3}\right]^{+}$species could be identified. As it was proved by the combined use of $\mathrm{pH}$-potentiometric, NMR and ESI-TOF-MS techniques, on increasing the $\mathrm{pH}$ the hydroxide ions are capable of replacing the chloride ligands resulting in the formation of $\left[\left\{\left(\eta^{6} \text {-arene }\right) \mathrm{M}\right\}_{2}\left(\mu^{2}-\mathrm{OH}\right)_{3}\right]^{+}$; chloride ions were shown to hinder the hydrolysis of the cations effectively. Regarding the electron donating effect of the hexahapto coordinating arene ligand, it was shown that there is a linear relationship between this capability (in the order of benzene < toluene $<$ p-cymene $<1,3,5$-triisopropyl-benzene) and the stability of the aquo complexes against hydrolysis allowing the fine tuning of the hydrolytic behavior of the half-sandwich type cations.
We have found that both primary and secondary monohydroxamates are capable of forming $(\mathrm{O}, \mathrm{O})$ chelated 1:1 complexes with high stability with the above metal ions in aqueous solution. Under basic conditions mixed hydroxo complexes were also identified. For primary hydroxamates where deprotonation of the hydroxamate- $\mathrm{NH}$ is also possible this species stabilized with an internal H-bonding was identified and above $\mathrm{pH} 10$ a further deprotonation process resulting in the formation of $\left[\mathrm{MAH}_{2}\right]$ type complexes was detected. Both types of ligand family were shown to form 2:2 complexes with the half-sandwich type metal ions in the solid state. In these complexes carbonyl-O donors coordinate to one of the metal centres while the hydroxamate-O-s bridge the two units. With the osmium-containing half-sandwich core redox reactions were also found during wich partial oxidation of the metal ion with subsequent loss of the arene ring and formation of an oxo-bridged dinuclear $\mathrm{Os}^{\mathrm{II}} / \mathrm{Os}^{\mathrm{VI}}$ hydroxamato complex was identified. Some of the $\mathrm{Ru}(\mathrm{II})$ and $\mathrm{Os}(\mathrm{II})$ complexes were screened against human-derived A2780 and A2780cisR (cisplatin resistant) cancer cell lines and showed no activity. This was interpreted with the low kinetic inertness of the complexes.

Regarding the amino derivatives of the hydroxamates having a terminal $-\mathrm{NH}_{2}$ group in chelatable position to the hydroxamate- $\mathrm{NH}$, formation of stable $(\mathrm{O}, \mathrm{O})$ and mixed $(\mathrm{O}, \mathrm{O})(\mathrm{N}, \mathrm{N})$ chelated mono- and dinuclear species was found in partially slow with á-alahaH and $\beta$-alahaH or in fast processes with ă-abhaH over a wide $\mathrm{pH}$-range indicating the generally more inert character of the $\mathrm{M}-\mathrm{N}$ bond in these complexes. The presence of the latter $\left[\mathrm{M}_{2} \mathrm{AH}_{1}\right]^{+}$type dinuclear species hindered effectively the hydrolysis of the metal ion under basic conditions and their stability showed a strong correlation with the size of the $(\mathrm{N}, \mathrm{N})$ chelates being the five membered one $(\alpha$-alahaH) is the most stable. Stoichiometry of these complexes was also proven in the solid state by the determination of the crystal and molecular structure of $\left[\left\{\left(\eta^{6}-\mathrm{p}-\mathrm{cym}\right) \mathrm{Ru}\right\}_{2}\left(\mu^{2}\right.\right.$-á-alahaH $\left.\left.\mathrm{H}_{-1}\right)\left(\mathrm{H}_{2} \mathrm{O}\right) \mathrm{Br}\right] \mathrm{Br} \cdot \mathrm{H}_{2} \mathrm{O}$ and $\left[\left\{\left(\eta^{6}-\mathrm{p} \text {-cym }\right) \mathrm{Ru}\right\}_{2}\left(\mu^{2}\right.\right.$-á-alahaH $\left.\left.\mathrm{H}_{-1}\right)\left(\mathrm{H}_{2} \mathrm{O}\right) \mathrm{Cl}\right] \mathrm{BF}_{4} \cdot \mathrm{H}_{2} \mathrm{O}$. Test of these $\mathrm{Ru}(\mathrm{II})$ complexes for their in vitro cytotoxicity using human ovarian carcinoma (A2780), human breast cancer (MCF-7), human ovarian adenocarcinoma (SKOV-3), human colon carcinoma (HCT-116) or human cervix adenocarcinoma (HeLa) cell lines indicated no anti-proliferative activity in the micromolar concentration range. 